Protecting Markets from Society: Non-Pecuniary Claims in American Corporate Democracy

\title{
Carl Gershenson
}

Harvard University

ABSTRACT: The state incentivizes investors to entrust capital to public corporations by granting shareholders enforceable rights over managers. However, these rights create legal "access points" through which social movements can make non-pecuniary claims on the corporation. I use original historical research on the Securities and Exchange Commission's administration of federal securities law to show that concern over non-pecuniary claims motivates the state to enact the role of "market protector." In this role, the Commission insulates managers of corporations from shareholders' claims that it deems illegitimate because they are insufficiently profit-oriented. Thus the inverse of Polanyi's observation that society protects itself from markets is also true: the state creates market boundaries so that "always embedded" markets function more like autonomous, profit-oriented markets. Accordingly, the extent to which corporate democracy represents general, social interests or narrow, profit-oriented interests is largely a function of political contestation and state policy.

To appear in Politics \& Society

Keywords: Markets, Corporate Democracy, Corporate Accountability, Economic Sociology, Political Sociology

Address: Carl Gershenson, Department of Sociology, Harvard University, 33 Kirkland St., Cambridge, MA, 02138. E-mail: cgershen@,fas.harvard.edu. 
In 1991, managers at Cracker Barrel Old Country Store, a popular restaurant chain, circulated a memo calling for the termination of employees who did not display the "normal heterosexual values which have been the foundation of families in our society." In response, an institutional shareholder submitted a proposal for inclusion on Cracker Barrel's proxy statement. This proposal would expand Cracker Barrel's anti-discrimination policy to include sexual orientation. Cracker Barrel's management decided to omit this proposal from the proxy. The Securities and Exchange Commission (SEC) approved management's decision, arguing that the institutional investor was interfering with the hiring and firing of low-level employees precisely the kind of "ordinary business decision" best left to the expertise of management. The institutional investor sued the SEC, embroiling the Commission in a prolonged legal dispute over the limits of corporate democracy in the United States. ${ }^{2}$

At this dispute's heart was the ability of shareholders to access the proxy statement, the main instrument of corporate democracy. Each year the statement is mailed to shareholders, who cast votes for directors and policy proposals. Qualifying shareholders have the right to place proposals on the proxy statement. These proposals cannot target the "ordinary business decisions" of the corporation unless they also implicate "substantial policy issues." Cracker Barrel case, the SEC wanted to make proxy access more restrictive by removing the "substantial policy issues" exception. In its place, the SEC proposed a bright-line rule that entirely sheltered employment policies from corporate democracy. Such a policy would empower management, but strip shareholders of the right to influence corporate practice in ways concordant with their values.

The Cracker Barrel incident is one episode in a long history of the SEC's contentious oversight of corporate democracy. This contentiousness stems from an internal contradiction of 
American corporate governance: the institutions that enable shareholders to undertake profitoriented behavior in securities markets simultaneously allow shareholders to subvert profitoriented behavior. That is, while capital markets cannot function without granting shareholders a strong set of enforceable rights over management, ${ }^{4}$ these same rights make it possible for policyoriented shareholders to make non-pecuniary claims on the corporation. These rights provide legal "access points" to corporate outsiders, but their effects receive little attention even in accounts of corporate governance most attuned to the role of politics. ${ }^{5}$ Most corporate governance scholars simply assume the primacy of profit-orientation among shareholders, managers, and other market actors.

No market is ever truly insulated from social forces, however often markets are treated as such. ${ }^{6}$ The discipline of economics -- especially financial economics -- is a major vehicle for the "ideological embeddedness" (or disembeddedness) of markets. ${ }^{7}$ Prominent economists have made normative claims as to the desirability of autonomous capital markets ${ }^{8}$ or work from the assumption that this description is accurate. ${ }^{9}$ Sociologists working in the tradition of Polanyi differ. Polanyi argues that as liberal forces pushed the market toward autonomy, society moved to protect itself, because unrestrained markets would lead to the destruction of land, labor, and capital.

This paper inverts Polanyi's dictum by asking how the market is protected from society. The market is "always embedded" in society. ${ }^{10}$ State and market are "co-constitutive," separated not by a wall but by a selectively permeable membrane. ${ }^{12}$ "Existential" and material motives are inseparable, even in markets and corporations. ${ }^{13}$ Yet very often, market actors pursue profits with little reference to struggles in nearby social fields. One goal of this article is to establish that this limited, de facto autonomy of the market is due to the state's insulation of 
corporate democracy from claims orthogonal to the profit motive. The state therefore contributes to the tendency of modern economic activity to unfold in a way that resembles the theoretical constructs of neoclassical economics. ${ }^{14}$ In this article, I show that the state does so by enacting two roles. As "market promoter," it establishes the shareholder rights that incentivize investors to enter capital markets. ${ }^{15}$ Because these very same rights make corporations vulnerable to claims by a variety of actors, the state as "market protector" administers these rights in such a way that profit-oriented investors are privileged over others. The twinned enactment of these roles is a necessary institutional support to the stability of a seemingly autonomous capital market.

However, the SEC's enactment of these roles meets trouble when social unrest spills over from civil society and into the market. These spillovers belie the naturalness of an autonomous market. A second goal of this article is to use the ecology of capital markets to explain why the SEC usually excludes, but sometimes invites, policy-oriented investors into the corporate governance process. To do so, I draw on the traditions in political and economic sociology that stress the social aspects of property rights, ${ }^{16}$ the state's role in reproducing capitalism, ${ }^{17}$ and the field-theoretic view of social conflict, states, and markets. ${ }^{18}$ These theoretical discussions prepare the ground for my case study of the development of federal securities law in the United States.

I use the concept of market protection to analyze the SEC's management of the legal access points created by proxy and disclosure law. In so doing, I demonstrate the analytic utility of a novel concept to literatures on the state and capitalism that have often remained rather abstract. ${ }^{19}$ I argue that the SEC has historically favored profit-oriented claims on the corporation over those derived from other motives. To achieve this insulation of the market, the SEC uses diverse legal strategies. Initially, the SEC erected an inviolable wall by declaring certain investor behaviors as illegitimate because their motives were not sufficiently "economic." The social and 
economic upheavals of the 1970s led the SEC to alter its approach to market protection, replacing the wall between market and society with a closely watched gate. Under the new regime, the SEC established discretionary rules for when policy-oriented shareholders would be granted access to corporate governance. Yet despite changes in SEC policy, the Commission's disadvantaging of non-pecuniary claims has been remarkably consistent. Thus, in the twinned roles of market promoter and market protector, the SEC devotes substantial resources to defining a market/society boundary and managing the extent of communication between the two. An understanding of these roles demonstrates that seemingly autonomous capital markets require continuous state intervention in the affairs of corporations.

\section{Theoretical Perspectives on State and Market}

\section{Economic Perspectives on Securities Law}

An influential series of papers by economists La Porta, Lopez-de-Silanes, Shleifer, and Vishny (LLSV) argue that the state promotes the development of stock markets by creating shareholder rights that address the principal-agent problem. LLSV and others ${ }^{20}$ see specialized securities laws as necessary to protect minority shareholders from expropriation by management and controlling owners. These economists stand in contrast to those who argue that the selfinterest of financial actors, coupled with the enforcement of private contracts, are sufficient preconditions for a healthy stock market. $^{21}$

The LLSV model rests on the assumption that investors use shareholder rights to pursue their economic self-interest: investors purchase corporate stock because they wish to own a share 
of the corporation's residual income. Accordingly, they purchase stock whenever they believe that the expected value of that revenue stream is greater than or equal to the price of that stock. However, the value of corporate revenue streams is subject to much uncertainty, which has the effect of depressing the price of stock. Can shareholders place proposals for profitable policies on the proxy statement? How accurate are corporate accounting records? If corporate insiders defraud shareholders, can shareholders be compensated for their losses? To the extent that the state provides legal solutions to these problems - through proxy law, disclosure law, and liability rules respectively - investors will be more willing to purchase corporate equity.

This model leads LLSV to predict a positive relationship between shareholder rights and the development of a nation's stock market. If shareholder rights incentivize small investors to enter the stock market, then stronger rights mean that a greater percentage of national wealth should be held in corporate equities. Shareholder rights should also be associated with more diffuse patterns of ownership, because protection from controlling shareholders allows minority shareholders to diversify their investments. In a series of papers, LLSV confirm that shareholder rights are associated with a nation's financial development and dispersion of ownership. ${ }^{22}$

\section{A Social Conception of Shareholder Rights}

The LLSV model shows that states may promote capital markets through legal institutions, but it misses tensions inherent in corporate governance because its treatment of shareholder rights stops at profit-oriented self-interest. Carruthers and Ariovich urge theorists to adopt a social conception of property rights, stating that "the right to control, govern, and exploit things entails the power to influence, govern, and exploit people. ${ }^{, 23}$ Similarly, I do not consider 
the market in corporate securities solely as a market in tradable claims on revenue streams. Rather, revenue claims are but one aspect of the contested bundle of rights and duties adhering to ownership of corporate stock. Some investors purchase corporate stock with the intent to use shareholder rights to do more than enhance the monetary valuation of their investment. ${ }^{24}$ These investors see the "power to influence, govern, and exploit" that adheres to property rights as a viable means to pursue ends of any kind. ${ }^{25}$ Power over management, no matter how slight, offers activists the ability to exert influence over the giant corporations that pattern multiple aspects of modern life.

The tendency of shareholders to exercise the social aspects of their rights depends on whether the political opportunity structure inclines activists toward lobbying the state or the corporation. ${ }^{26}$ While the following history may make activists' dogged efforts to effect change through securities law seem futile, there is substantial evidence that these strategies can affect corporate behavior. Corporations have few routinized practices to respond to challenger groups, and so are vulnerable to disruption by delegitimization. ${ }^{27}$ Legitimacy concerns are salient enough to management that shareholder activists can "coerce" corporations to adopt new forms of organizational structure. ${ }^{28}$ Studies point to the ability of activists to pressure corporations and achieve limited social ends. ${ }^{29}$ Policy-oriented shareholder actions can also affect the valuation of corporate property. ${ }^{30}$ Social movements, then, can use shareholder rights to disrupt the autonomy of capital markets and precipitate social change. Accordingly, traditional accounts of the corporation from the perspective of management-owner struggles over residual income are incomplete without reference to the civil fields in which markets are embedded.

The state's disposition toward shareholder activism also contributes to activists' understanding of the opportunity structure. There are brief periods when the state becomes 
receptive to stakeholders' non-pecuniary claims. The case study below demonstrates that these periods are best explained by the ecology of capital markets.

\section{The State's Support for Stability through Mediated Change}

Theorists of the capitalist state argue that state managers act in ways that tend to reproduce capitalism. ${ }^{31}$ To do so, the state often enacts polices that buttress markets in the long run, but which business interests oppose nonetheless. State managers can only enact these policies if they retain considerable autonomy from business. ${ }^{32}$ Yet state managers cannot seek complete autonomy from business interests, or else they isolate themselves from informational channels that aid economic policymaking. ${ }^{33}$

How do state managers maintain autonomy from business interests, and yet retain the closeness and power to (when needed) intervene effectively in corporate affairs? One answer comes from the state's ability to influence the ecology of capital markets: state managers can set themselves up as intermediaries between corporate fields and social movements by creating legal boundaries around markets and civil society - a definitional act that neatly places the state outside of both as well. The state has the incentive to insulate markets from other fields, because, as Fligstein and McAdam ${ }^{34}$ argue, social change comes in cascades, rolling from one field to the next. Stability-seeking incumbents in states and markets therefore value stability not just in their own field, but also in fields proximate to their own. However, unless these actors have actual power over nearby fields, they cannot directly promote stability in them. In such a case, stabilityseeking actors will instead prioritize the separation of key fields from potentially destabilizing fields, such as those that contain contentious social movements. Hence, state agencies will enact 
the role of market protector by trying to separate markets from social movements whenever possible.

Conversely, social movements will attempt to manipulate field ecology to precipitate change. They use legal access points to institutionalize themselves as challengers in markets, the state, or other fields that might set off a cascade of rolling, field-to-field change. The goal of these social movements is not to win any particular shareholder challenge, but to routinize the representation of their movements' views within the corporate governance process in the long run. ${ }^{35}$ Social movements should be most likely to target corporations where neoliberal economic policy has led to weaker states -- or at least, to states that are less likely to intervene visibly in the economy. ${ }^{36}$ Social movements' use of shareholder rights in particular should have become more common as the economy became increasingly "formatted" by capital markets during the late $20^{\text {th }}$ century. ${ }^{37}$ Under such a political and economic regime, those desiring social change may anticipate larger returns from targeting corporations than states. ${ }^{38}$

Wariness of systemic instability leads the state to temper its market protection by making concessions to social movements during periods when anti-corporate sentiment is high. ${ }^{39}$ When a social movement has attained a certain amount of power or legitimacy, state-enforced restriction of its access to markets may simply destabilize the situation further by encouraging nonroutinized forms of political contention. ${ }^{40}$ The refusal to acknowledge claims coming from social movements may lead to a spiral of increased participation and sympathy for the social movement. ${ }^{41}$ The state may see the channeling of social discontent into corporate democracy as a "safety-valve institution" 42 preferable to risking conflict expansion in the prolonged struggle to suppress political contention. ${ }^{43}$ Thus the state's "stabilizing hand" 44 should not be confused as a preference for stasis, but rather for mediated change. 
In this case study, the "stabilizing hand" of the SEC is most visible following the Watergate scandal. During this period, the SEC embraced a more robust version of corporate democracy that acknowledged both profit-oriented and values-oriented investors. The SEC's actions channeled public anger into routinized corporate process, and helped to re-legitimate both state and market. In 1976, the SEC accommodated the growing power of social

movements, ${ }^{45}$ institutional investors, and shareholders' rights activists ${ }^{46}$ by routinizing - but still limiting -- their access to markets. The SEC's actions post-Watergate show that the primary goal of its staff and Commissioners is the preservation of a liberal market society. When this goal is not threatened, the SEC then pursues its secondary goal of protecting the market from disruptive challengers so that corporations may operate as if markets were autonomous.

\section{Data and Methods}

This article draws on both primary and secondary source materials, including articles in law journals that were written by participants in these legal struggles. ${ }^{47}$ I used the Lexis-Nexis legal database to obtain judicial opinions cited in secondary materials or as precedent in other judicial opinions. I obtained federal statutes or instances of federal rulemaking (as would appear in the Federal Register) referenced by opinions or secondary sources. Additional searches were made for judicial and administrative decisions that were not cited by future decisions. However, the secondary literature seems reasonably comprehensive in its documentation of administrative and judicial precedent.

For the crucial decade of the 1970s, I have gathered additional archival materials. Foremost among these are records of communication between the SEC and professional 
audiences. These letters, memoranda, and addresses have been curated and made available by the SEC Historical Society. Far from "cheap talk," the public addresses analyzed below were understood by their speakers ${ }^{48}$ and audiences ${ }^{49}$ as instances of informal rule making. These speeches were disseminated in print to the wider community of securities professionals, either through publication in journals such as Business Lawyer or by the SEC itself. Finally, I used Lexis-Nexis to obtain transcripts of Congressional hearings (and their associated committee reports) concerning SEC activities or where SEC commissioners testified. These sources provide a valuable outsider perspective on the policies discussed elsewhere by securities professionals. ${ }^{50}$

Methodologically, this article has two goals. First, I use an intensive case study to facilitate theory building around the state and markets. ${ }^{51}$ Market protection is presented as a sustained political process, with the location of the market/society border an object of continual contestation.

Secondly, this article provides an explanatory framework for the degree of state participation in market protection. A within-case comparative logic ${ }^{52}$ allows for an assessment of the role of political and economic factors as explanatory variables beyond a correlational approach. For example, significant leeway was granted to values-oriented shareholders by the Republican-dominated Commissions appointed by Presidents Nixon, Ford, and Bush Sr. A simple correlational approach might suggest that Republican commissioners are less concerned with market protection than Democrats. However, closer analysis shows that Republicanappointed commissioners never weakened market protection without external pressures. Instead, I argue that continuity of state purpose underlies the occasional lurches in SEC policy. No matter which party controls appointments, the SEC has demonstrated a constant preference for market protection. This argument provides a parsimonious explanation for why the diverse set of legal 
devices and interpretations issued by the SEC since 1934 tend to have a similar effect, namely the insulation of securities markets from non-pecuniary claims. As I demonstrate with my analysis of the post-Watergate era, lapses in market protection occur only during times of mobilized opposition, when expanded corporate democracy helps reestablish the legitimacy of markets.

The first part of this case study follows the building up of an administrative common law around the "proper subjects" of corporate democracy. During this period, the SEC established rights of shareholders over management, but also erected a wall between market and society. The second section concerns the SEC's sudden (but temporary) abandonment of market autonomy in the face of the destabilizing shock caused by Watergate. The third section follows the SEC as it routinizes policy-oriented activists' participation in corporate democracy and administers a less strict, "gatekeeping" realization of market protection. The final section shows the SEC attempting to return to the complete market/society separation of the pre-Watergate era. However, the Commission eventually realizes that bright-line rules are untenable due to the embeddedness of markets.

\section{American Securities Law and the Separation of Market and Society}

\section{The SEC as Champion of Shareholder Rights, 1934-1953}

The SEC is an independent regulatory agency created in 1934 to administer the newlypassed federal securities laws. The president, with the advice and consent of the Senate, selects

nominees for five-year terms on the Commission. Although commissioners operate with 
considerable independence from the executive branch after their appointment, the failure of most commissioners to complete a full five-year term gives presidents significant control over the Commission's ideological composition. ${ }^{53}$ Congress exerts influence indirectly via hearings ${ }^{54}$ or directly through the budget and legislation altering the SEC's mandate. Meanwhile, courts may overturn the Commission's decisions, rulemaking, and interpretations of state and federal securities law. Until recently, however, Congress and the courts have exhibited substantial deference to the SEC. ${ }^{55}$ This deference has been fairly consistent, even though it is typical for staff and commissioners (who are generally attorneys with backgrounds in securities law) to join the private sector upon leaving the SEC. ${ }^{56}$ Despite its close relationship with the private sector, the SEC nonetheless maintained a reputation for effective enforcement through the $20^{\text {th }}$ century. ${ }^{57}$

The SEC was a champion of shareholder rights for its first two decades of existence. Commissioners in these early years promoted capital markets through the establishment of the shareholder rights measured by the LLSV index. Of these rights, I have chosen to follow the development of the proxy rules, as they "reflect the most extensive intrusion [of federal securities] law into the internal affairs of the corporation." ${ }^{58}$ Shareholders have the right to elect the board of directors and vote on issues of corporate policy. Most shareholders who participate in corporate democracy do so through the proxy statement, which is sent out to shareholders. The content of the proxy statement is generally determined by corporate insiders like management and the board of directors. However, even minority shareholders have the right to place proposals on the proxy statement.

The SEC first defended shareholders' right to proxy access when it aided the Gilbert brothers in their 1939 struggle to place a proposal on Bethlehem Steel's proxy statement. To do 
so, the Commission amended the proxy rules in a manner favorable to shareholders. ${ }^{59}$ In 1942 , the SEC further decided that if a qualified security holder "intends to present for action at a [shareholders' meeting] a proposal which is a proper subject for action by the security holders, the management shall set forth the proposal [on the proxy statement]. ${ }^{, 60}$ However, no elaboration was given of what a "proper subject" for action might be.

This ambiguity spooked some observers, as demonstrated in a Congressional hearing concerning the 1942 amendments:

Rep. Boren (D-OK): So one man, if he owned one share in A.T.\&T. and another share in R.C.A. . . he could have a hundred-word propaganda statement prepared and he could put it in every one of these proxy statements ... Suppose a man were a Communist and he wanted to send to all of the stockholders of all of these firms, a philosophic statement of 100 words in length, or a propaganda statement. He could by the mere device of buying one share of stock have available to him the mailing list of all the stockholders in the Radio Corporation of America. ${ }^{61}$

In response, SEC Commissioner Purcell promised that the SEC would protect corporations from such issues as they occurred. This exchange makes clear that despite the Commission's earlier pretensions that proxy statements could "approximate the conditions of the old-fashioned meeting, ${ }^{, 62}$ corporate democracy by proxy would require significant restrictions in the freedom of shareholder's speech. Otherwise, a schematic reading of these rights would lead to an inundation of the proxy statement by issues unrelated to the profitability of the firm. 
The SEC first shielded management from policy-oriented shareholders in 1945. An industrial corporation asked the SEC to approve the exclusion of a shareholder resolution that proposed a vote on the desirability of several investor-friendly federal policies. The SEC supported the proposal's exclusion and issued an interpretive release:

Speaking generally, it is the purpose of Rule X-14A-7 to place stockholders in a position to bring before their fellow stockholders matters of concern to them as stockholders in such corporation ... It was not the intent of Rule X-14A-7 to permit stockholders to obtain the consensus of other stockholders with respect to matters which are of a general political, social or economic nature. Other forums exist for the presentation of such views. ${ }^{63}$

While feeling out the mood of the room on economic reforms might have been possible in an "old-fashioned meeting," the SEC makes it clear that the proxy statement was not to be used for such general purposes. Rather, shareholder proposals could only target issues relating directly to the corporation. The release's reference to "other forums" and the creation in 1948 of a list of "enumerated exceptions" to proxy access hint at a "logic of appropriateness" argument that stock markets and social change are poor fits. ${ }^{64}$

The 1945 decision involved one of the earliest instances of the "proper subject test." This test is initiated when management writes to the SEC asking for permission to omit a shareholder's proposal from the proxy statement on the grounds that the proposal is not a "proper subject" for corporate democracy. If the SEC agrees, it issues a "no-action letter" in support of the omission. When applying this test, the SEC is supposed to defer to the laws of the state of 
incorporation. However, influential securities law scholar Louis Loss notes, "Inevitably the Commission, while purporting to find and apply a generally nonexistent state law, has been building up a 'common law' of its own as to what constitutes a 'proper subject' for shareholder action." ${ }^{\circ 5}$

The SEC revisited "proper subjects" in 1951 after a civil rights activist submitted to the Greyhound Corporation a proposal recommending that "management consider the advisability of abolishing the segregated seating system in the South. ${ }^{, 66}$ This resolution did concern policy directly relevant to Greyhound's main business; nonetheless the SEC allowed Greyhound to exclude the proposal. To support this decision, the SEC amended the proxy rules by stating that a corporation did not have to include a proposal "submitted by the security holder primarily for the purpose of promoting general economic, political, racial, religious, social or similar causes. ${ }^{, 67}$ Thus the scope of shareholder rights was narrowed further: the SEC insulated management from proposals motivated by a concern for a "general" cause, even if the proposal concerned the corporation directly. By similar reasoning, the SEC also approved the exclusion of shareholder proposals that an investment firm divest from liquor stocks, and that another company extend to women the same pension benefits as it offered to men. ${ }^{68}$

However, the 1945, 1948, and 1951 rulings should not be interpreted as a general weakening of SEC support for shareholder rights. In fact, this period saw the SEC's most lasting achievement in market promotion. When the management of Transamerica Corporation refused to place the Gilbert brothers' shareholder rights proposals on Transamerica's proxy statement, the SEC brought suit. In 1947, the $3^{\text {rd }}$ Circuit Court ruled in favor of the SEC, citing the intent of the New Deal congress to establish shareholder rights as a counterweight to the power of management. ${ }^{69}$ The SEC was therefore instrumental in establishing the right of 
shareholders to access the corporate proxy statement. This right is one of the pillars of corporate democracy, the most significant federal intrusion into corporate governance, ${ }^{70}$ and is instrumental in promoting mature financial markets. ${ }^{71}$

\section{The SEC as Qualified Champion of Shareholder Rights, 1953-1972}

The business community saw the Eisenhower administration as an opportunity to reassert the supremacy of management in corporate affairs. The new SEC chairman was dismissive of the value of shareholder proposals. At a public hearing, a business representative estimated that the cost of shareholder proxy access was around $\$ 60,000$. The SEC chairman replied: "I suppose that $\$ 60,000$ to the American Telephone Company isn't much but if it isn't accomplishing anything then it does not serve any useful purpose."72

While Eisenhower's SEC did not abandon shareholders' right to proxy access, it did severely restrict it by establishing what was called the "ordinary business rule." The chairman likened this rule to using "a screen with a somewhat closer mesh."73 This rule attempted to draw a distinction between "ordinary," day-to-day operations and long-term corporate policy. The latter was the domain of shareholders, while the former was reserved solely to managerial discretion. A judge later attributed the ordinary business rule to the SEC's realization that "management cannot exercise its specialized talents effectively if corporate investors assert the power to dictate the minutiae of daily business decisions." ${ }^{\prime 74}$ Thus, the SEC placed the vast majority of business activity outside the jurisdiction of shareholders.

The "ordinary business rule" rule does not inherently define market/society boundaries, as did the three previous rulings on the impermissibility of general social concerns as investor 
motives. Nonetheless, the flexibility of the ordinary business rule turned it into the linchpin of many such market-protection efforts because it provided a plausible rule by which to shield the majority of corporate decisions from shareholders' influence. ${ }^{75}$ The justification for the rule is that profit-oriented shareholders are best served by restraints on shareholder power. However, this reasoning disregards the myriad non-pecuniary motives shareholders might have for proposing a change in a corporation's day-to-day activities. After all, there is no reason to assume that a corporation's ordinary decisions have less profound of an impact on social outcomes than do their "extraordinary" business decisions. Furthermore, there is no reason to assume that the "specialized talents" of management in efficient operations extend to moral reasoning.

The SEC's use of the ordinary business rule to protect markets from policy-oriented claims is clearest in two no-actions letters issued in 1969. These were elicited by the Medical Committee on Human Rights' (MCHR) attempts to discourage the use of napalm in the Vietnam War. Recognizing that the Greyhound no-action letter required shareholders to frame proposals in the language of profit motives, the MCHR first proposed that Dow cease selling napalm to buyers (i.e. the U.S. Army) intending to use it on human beings, because failure to do so would have an adverse economic impact on the corporation. The SEC issued a no-action letter, reasoning that shareholders have no power over to whom and under what conditions a corporation sells products. This was an "ordinary business decision" that should be treated as legally separate from the kinds of economic strategies that shareholders could vote on. Accordingly, MCHR reframed its petition in terms of a broader economic strategy, proposing that Dow cease napalm production altogether. The SEC issued another no-action letter, again 
using the ordinary-business language to assert that management has sole discretion over the decision to enter or exit product lines. ${ }^{76}$

\section{A Wall Between Market and Society: 1934-1972}

The pattern of SEC rulings up to this point in 1972 is straightforward. The SEC stopped expanding shareholder proxy rights once it had established those in Transamerica. In fact, Transamerica was the only proxy access-related enforcement action the SEC brought against a corporation, while it blocked at least 1,000 proposals. ${ }^{77}$ After Transamerica, each time a shareholder attempted to use proxy laws for a purpose other than profit, the SEC would issue a no-action letter that narrowed the scope of corporate democracy further. Federal law thus restricted corporate owners in terms of the target, motives, and level of their proposals. These three constraints on shareholder activity allowed the SEC to insulate management by creating boundaries around the market. By policing this boundary, the SEC granted management and investors the autonomy to pursue profit-oriented behavior without having to acknowledge policy-oriented challengers. The SEC had overseen the transformation of corporate democracy from the formal equivalent of open-ended face-to-face meetings to the right to propose profitoriented general strategies.

The SEC's uncompromising market protection was unlikely to survive the 1970 s for several reasons. First, the members of the "social movement generation" ${ }^{18}$ were attaining the resources and skills to mount legal challenges to contest no-action letters. Significantly, MCHR's legal victory over the SEC in the U.S. Court of Appeals established a legal precedent for policyoriented proxy access. Secondly, the frequency of these challenges increased as this innovative 
protest strategy diffused, due to the founding of the Interfaith Center on Corporate Responsibility in $1971^{79}$ and the highly publicized actions of activists like Saul Alinsky in Rochester, NY and Ralph Nader in Campaign GM. ${ }^{80}$ The SEC supported exclusion of Campaign GM shareholder proposals dealing with air pollution, mass transit, minority opportunity, product safety, and employee safety. ${ }^{81}$ Nonetheless, organizers considered Campaign GM a success because of its high visibility. Public pension would become particularly effective practitioners of this form of activism, due to their size and ability to maintain a constant presence in the legal system and engage in a long-term struggle for favorable precedents. ${ }^{82}$ Furthermore, the coming-of-age of "agency theory" in the $1970 \mathrm{~s}^{83}$ lent an intellectual legitimacy to institutional investors' exercise of authority over management that was unavailable to the religious groups who pioneered shareholder social activism. ${ }^{84}$

Most fundamentally, the SEC's rigid market protection faltered because of its untenable insistence on the separateness of market and society. This failure to grasp the inherent embeddedness of markets is apparent in Supreme Court correspondence concerning the MCHR v. SEC case. Justice Blackmun wrote that the case seemed fairly straightforward to him: Dow's production of napalm is clearly the kind of ordinary decision that the SEC intended to shield from shareholder influence. However, he regrets that the case was "tainted" by Vietnam "overtones." Blackmun speculates that if MCHR had pressured Dow management over a product not tainted by the war - for example, traveling bags -- then the case would never have reached the Supreme Court. ${ }^{85}$

Justice Douglas, offering the lone dissent on the decision to render MCHR v. SEC moot, quotes Galbraith's New Industrial State to present a contending view: 
The modern super-corporations, of which Dow is one, wield immense, virtually unchecked, power. Some say that they are 'private governments,' whose decisions affect the lives of us all. The philosophy of our times, I think, requires that such enterprises be held to a higher standard than that of the 'morals of the marketplace' which exalts a single-minded, myopic determination to maximize profits as the traditional be-all and end-all of corporate concern. ${ }^{86}$

Justice Blackmun's imaginary abstracts away social entanglements in order to better get at the technocratic intentions of SEC rulemaking. Meanwhile, Justice Douglas calls for abandoning state support of market autonomy. Douglas realizes that no product line is ever fully disentangled from social concern, nor is the degree of entanglement a fixed quantity. "The philosophy of our times" would wear down the legitimacy of markets protected from social movements by bright line rules, and Douglas would prove to be the more prophetic justice as once innocuous products and practices became contentious.

\section{Watergate and the Activist SEC, 1972-1976}

The SEC unexpectedly abandoned the principle of market/society separation during the second Nixon administration. The Watergate scandal - which led to the revelation of corporate violations of SEC accounting standards -- caused public disillusionment with government and business. Given the public's mood, the SEC saw recognizing claims regarding the "integrity of management" as the surest path back to market stability. The Commissioners hoped that encouraging such moralized claims would help to re-legitimate business --- and the SEC, as well. 
This episode shows that the SEC's preference for system stability overrides its preference for an autonomous market.

Disclosure law is the other leg (along with proxy law) on which corporate democracy stands. Disclosure law covers management's obligation to make public all "material" information that might influence stock prices or influence a corporate election. Material information usually refers to basic financial information, but it may also indicate any fact "that a reasonable stockholder would want to know." ${ }^{97}$ For example, information on the "integrity of management" may sometimes be considered material. ${ }^{88}$

Disclosure law played an often forgotten role in the Watergate investigation. The director of the SEC's Enforcement Division was worried about the illegal contributions certain corporations had made to the Committee to Re-elect the President. The invisibility of these large expenditures on official accounting records implied that something was broken with the SEC's oversight of corporate disclosure. The Enforcement Division soon discovered that corporations had used off-the-books "slush funds" to make even more "questionable payments" than had been detected by the Watergate Special Prosecutor ${ }^{89}$ Many bribes had gone to foreign officials, and so did not violate existing anti-bribery statutes. Furthermore, many bribes were small enough that they did not represent an economically material expenditure. With Watergate in the background, however, the SEC decided that even small, legal bribes were material because an investor might consider them when making inferences as to the moral integrity of management. This legal theory came to be called "qualitative materiality." "90

Director Sporkin convinced the SEC's five-member Commission to bring enforcement cases against those corporations that had failed to inform investors of their involvement with acts of questionable morality. This was surprising, given the SEC's history of insulating markets 
from moral concerns. To explain this unusual episode, I focus on the two commissioners who eventually opposed using securities law for explicitly moral purposes. This period generated an unusually explicit discourse on morality in markets, allowing me to present the "least-likely" commissioners' understanding of the SEC's role in the market in their own words. I provide passages from the commissioners' addresses to securities professionals, followed by multiple citations to establish the representativeness of this rhetoric.

The commissioners' response to Watergate was to reconceptualize their role in maintaining the stability and legitimacy of state and market. In particular, the commissioners feared that the bribery scandals had destroyed the reputation of the business community. The Commission now felt that stability was best achieved by inviting ethical claims into the market with the hope that these claims might imbue the market with moral legitimacy. This motive is apparent in their speeches, where Chairman Garrett and Commissioner Sommer present themselves as protectors of American capitalism itself. They no longer ask the technocratic question: has the SEC established an autonomous market wherein profit-oriented behavior predominates? Instead they focus on whether the SEC's actions will re-legitimize American business.

These commissioners believed that inaction might lead to unwelcome upheaval in the American economic governance. In a 1974 address, Chairman Garrett tells securities professionals that the American system of securities regulation is "passing through a dangerous period. ${ }^{" 91}$ Garrett stresses that the alternative to New Deal securities regulation is not the light hand of the Lochner Era, but something even more statist: "[I do] not want to see the overthrow of our continued reliance on the small governmental police force and big voluntary compliance from the private side. ${ }^{, 92}$ Garrett invokes the threat of a populace disenchanted with capitalism: 
It is no secret, however, that there are others who are not so wedded to this method of organization, and corporate directors should be conscious of the fact that their total activity . . . is under scrutiny today by many persons, including those who appear eager to find excuses for claiming that the system does not work. $^{93}$

To ward off any such upheaval, the SEC addressed what the public saw as moral, not technical, failures of the American system. Garrett wanted to stabilize the market through the restoration of the moral legitimacy of business and government: "We must restore confidence, not just in the technical competence but in the moral adequacy of our leadership, economic as well as political."94 Commissioner Sommer also began to see the SEC as a guardian of the market's reputation, citing the "flexible ability [of securities law] to respond to the ethical conceptions which the public demanded be translated into legal mandates . . . [without which] I think we would have had an even greater erosion of confidence in corporate responsibility and corporate decency than we have had." $" 95$ This quote is an especially direct explanation of the SEC's decision to begin welcoming moral claims into the marketplace.

The Commissioners did not want to overthrow the system, but wanted to achieve stability through mediated change. Although Garrett was championing innovation in securities regulation, he saw the thrust of his policy as profoundly conservative and American:

The principles of the federal securities laws are central to the maintenance of our free enterprise system . . This is a profoundly conservative policy, fully 
consistent with the principles announced in the Declaration of Independence, but the price of preserving it, like liberty itself, is eternal vigilance. ${ }^{96}$

However far Garrett and Sommer went in championing enforcement cases based on "qualitative materiality," the other commissioners went further by arguing that materiality should be expanded beyond the bribery and corruption issues raised by Watergate. For example, one commissioner argued that materiality standards required disclosure of corporate participation in the Arab boycott of Israel. ${ }^{97}$ Although the SEC had started its investigation of questionable payments without Congressional prompting, representatives made aware of the issue urged the Commission to do more than it had. ${ }^{98}$

By late 1975, these expansive interpretations of materiality spooked Garrett and Sommer. They knew that qualitative materiality bespoke the lack of a firm and fixed line between market and society. The two commissioners then attempted to reestablish that boundary by denying anew the legitimacy of non-pecuniary claims in corporate governance. Garrett thus asserts that he only objects to corporate immorality that "might be expensive to the investors" 99 and that the SEC is indifferent to how "the corporation treats the rest of the world."100 The SEC does not have a "mandate to enforce, even indirectly, through compulsory disclosure, all of the world's laws and all of its perceptions of morality and right conduct."101 Garrett cannot satisfy ethical investors without "opening the door to further intrusions ... . [that] disclosure procedures and requirements be used to help enforce policies increasingly remote from investor protection in the classical, or financial and economic sense."102 By welcoming moral claims into the market, the SEC had "punched a tar baby."103 Unless the SEC began to disallow moral claims now, 
materiality would expand indefinitely through the righteous demands of the "purity potlatch.",104 Meanwhile, Sommer wonders:

Must we compel the disclosure of the fact that the chief executive officer occasionally shows up drunk at the office, or that the treasurer is under investigation by the IRS, or that the executive vice president is having an affair with his secretary, or that the executives use the company's jet for personal purposes on occasions? The implications of these concepts are limitless - and troubling. ${ }^{102}$

Though the staff and several commissioners continued to support qualitative materiality into the 1980s, the federal judiciary effectively ended the SEC's activist phase in the late 1970s. ${ }^{106}$ However, the flexibility of the SEC during this period helped to reestablish the damaged moral legitimacy of transnational corporations, thereby staving off more direct challenges to the autonomy of markets.

\section{The SEC as Gatekeeper, 1976 - 1991}

During the height of SEC activism, the Commission created the "two-pronged test," which had a more lasting effect on corporate governance than qualitative materiality. ${ }^{107}$ This test was perhaps an effort to preempt more drastic action from Democrats in Congress, who wanted to establish through legislation the right of shareholders to pursue political and ethical goals. ${ }^{108}$ The two-pronged test replaced the bright-line separation of market and society with ad hoc decisions about the excludability of shareholder proposals. Proposals were excludable if they 
concerned ordinary business decisions (prong one), but not if they also had "substantial policy implications" (prong two). The reference case for the two-pronged test was a decision that a "proposal requesting company not to construct nuclear power plant may not be excluded even though the proposal also relates to the mundane matters of the fuel mix and types of electrical generating methods." ${ }^{\prime 109}$ The SEC decided that shareholder concern over the danger to their community presented by radiation and nuclear meltdown rendered "the mundane matters of fuel mix" proper subjects for corporate democracy, thereby allowing policy-oriented investors limited access to the corporation.

Screening for the Profit-Oriented Investor, 1983-1988

The election of Ronald Reagan ushered in an SEC regarded as significantly more business-friendly than that of the Ford and Carter administrations. ${ }^{110}$ Nonetheless, instead of discarding the two-pronged test, Reagan's SEC amended the proxy rules in a way explicitly intended to discourage "abuse" of the proxy statement by those who did not have an "investment interest" in the corporation. ${ }^{111}$ These amendments were legal innovations in the SEC's continuing efforts to disadvantage non-pecuniary claims on the corporation.

The first new rule allowed management to exclude shareholder proposals that concerned "operations which account for less than five percent of the issuer's gross assets." ${ }^{112}$ This rule bluntly equated the insignificance of a business practice on a balance sheet with the social insignificance of that practice. This rule was used by the management of Iroquois Brands to omit a shareholder proposal to: 
... study the methods by which its French supplier produces paté de foie gras, and report to the shareholders its findings ... on whether this production method causes undue distress, pain or suffering to the animals involved and, if so, whether further distribution of this product should be discontinued until a more humane production method is developed. ${ }^{113}$

Management argued that sales of foie gras made up a very small percentage of Iroquois' revenue, and so shareholders could not legally target foie gras with proposals. While a federal court supported the shareholder in this case, the SEC's rule stood.

The second rule attempted to sort between investors who had demonstrable "investment interest in the corporation" from those who did not, by requiring those placing proposals on the proxy statement to own either $\$ 1,000$ of shares or $1 \%$ of outstanding shares for at least a year. Both Reagan-era rules bear a functional resemblance to the 1951 Greyhound ruling, which allowed proxy access only to shareholders with "economic" motives. Altogether, Reagan's SEC found ways to discourage the use of shareholder rights by ethical investors without discarding the two-pronged regime worked out in the previous decade.

Instability in SEC Gatekeeping, 1988-1992

The ad hoc system of the two-pronged regime operated quietly until the late 1980s, when the rate of policy-oriented shareholder proposals nearly doubled. ${ }^{114}$ As large public pension funds became more likely to sponsor these proposals, an increasingly large number achieved some level of success. ${ }^{115}$ Perhaps acknowledging a shift in power toward investors, the SEC 
reversed a number of its own precedents on the excludability of shareholder proposals over a span of four years. In each case, the justification for the SEC's reversal involved growing public discontent and increased interest from state and federal officials with corporate practices that had previously been deemed "ordinary" from a business standpoint, yet which were becoming "substantial" from a policy standpoint. ${ }^{116}$ These reversals allowed shareholders to submit proposals on formerly "ordinary" topics such as the location of corporate property (e.g. plant closings), which products firms will market (e.g. tobacco products), and the size and structure of executive compensation (e.g. golden parachutes conditional on the CEO's completing a merger). A summary of key reversals is provided in the Appendix.

From one perspective, the two-pronged regime was successful. The SEC avoided damaging lawsuits, bad publicity, and conflicts with Congress because it retained flexibility in making ad hoc decisions on the excludability of proposals. Flexibility was necessary because the contours of public opinion on issues like tobacco change with time, and SEC policy had to change with public opinion in order to preserve the legitimacy of shareholder democracy. Activists' knowledge of this flexibility explains somewhat the continued popularity of shareholder activism despite the many legal barriers placed in its way. From the activists' perspective, these reversals implied that no-action letters were only a temporary hindrance to any given issue being included on proxy statements. After all, a long history of no-action letters on an issue demonstrated the existence of "widespread public debate" on that issue, which could then be treated as evidence under the two-pronged regime that the issue should be allowed on the proxy statement.

At the same time, the flexibility of the two-pronged regime was costly to the SEC in terms of staff resources, ${ }^{117}$ especially now that the rate of policy-oriented proposals had almost 
doubled compared to a decade earlier. Flexibility also irked the SEC's corporate constituency, which preferred the predictability of a bright-line rule to the vagaries of the two-pronged test. ${ }^{118}$ Many at the SEC agreed, and they saw the Cracker Barrel case, described in the introduction, as an opportunity to reassert the old "ordinary business rule," which excluded even "substantial" policy issues from corporate democracy.

\section{Giving Up on a Bright-Line Rule, 1992-Present}

The Cracker Barrel case gave the SEC the opportunity to reassert market autonomy by ruling that the decision to hire and fire ordinary employees was too fundamental to corporate operations to allow interference by shareholders. This decision reversed precedent that equal employment-opportunity concerns were substantial policy issues that trumped the ordinary business rule. A legal victory by the SEC in the Cracker Barrel case would have opened up the possibility of ever more bright-line rules establishing the excludability of other substantial political issues.

In 1995 the $2^{\text {nd }}$ Circuit Court upheld the SEC's decision to cease administering the policy prong of the two-pronged test. However, political pressure to reverse its decision built on the SEC. The National Securities Markets Improvement Act of 1996 may be the reason for the SEC's reversal. ${ }^{119}$ This act directed the SEC to conduct a study on proxy access for social issues. In 1998, the SEC announced it would return to a case-by-case approach, acknowledging, "there is no bright-line test to determine when employment-related shareholder proposals raising social policy issues fall within the scope of the "ordinary business" exclusion." 22 
With that release, the SEC agreed to allow policy-oriented investors limited access to the corporation. The post-Cracker Barrel SEC has not reached a new equilibrium on proxy law. Despite some new guidance on the ordinary business rule, ${ }^{121}$ legal experts agree that the rules surrounding proxy access remain ambiguous. ${ }^{122}$ For example, in 2008 the SEC allowed corporations to omit proposals that sexual orientation and gender identity be included in nondiscrimination policies, seemingly reversing the Cracker Barrel reversal. ${ }^{123}$ However, since the financial crisis and the Dodd-Frank Reform Act of 2010, debate over proxy access has largely shifted to shareholder influence on director elections. ${ }^{124}$ The striking down of an SEC rule concerning nomination of directors in the Business Roundtable decision has increased the uncertainty surrounding SEC rulemaking in general. ${ }^{125}$ In short, since Cracker Barrel the Commission has eschewed the creation of new bright-line rules for a case-by-case approach to proxy access. This suggests that the SEC has accepted the untenability of enforcing a rigid market/society boundary. This lack of a bright-line rule gives activists and corporations the incentive to contest what may seem like otherwise settled issues surrounding proxy access. The exact contours of the market/society boundary, then, remain an outcome of the interaction of the state, managers, investors, and social movements.

\section{Conclusion}

The SEC oversees capital markets by enacting two roles. First, it promotes markets by establishing shareholder rights that align the interests of management with those of shareholders. However, these rights create "access points" from the social fields in which markets are embedded. Because social forces inevitably spill over into market activity, the SEC protects 
markets by administering shareholder rights so that the interests of shareholders (and by extension, management) are dominated by profit-oriented concerns. According to economic theory, the aggregate effect of shareholders pursuing their financial interests is an autonomous market that rationally allocates capital to its most efficient uses in the economy, thereby maximizing social welfare. ${ }^{126}$ Therefore to the extent that the capital market resembles the autonomous markets of economic theory, this is because the state successfully promotes investment in capital markets and protects these markets from non-pecuniary claims.

To appreciate the dependence of market autonomy on the state, consider two alternatives closer to libertarian and contractarian preferences: leaving the settlement of corporate governance disputes to the courts and leaving the settlement of disputes to processes internal to the corporation. Federal judges, as generalists, have demonstrated less concern with marketmaking projects than the specialists at the SEC. From the history above, it is clear that the judiciary has been more likely to balance "non-economic" perspectives in rulings on shareholder rights. The judiciary has significant leeway to do so, because judgments as to whether a business decision is "ordinary," whether a policy interest is "substantial," or whether a shareholder's motive is "economic" all require significant interpretive work. Furthermore, the institutional structure of the judiciary makes it less predictable than the SEC. The SEC tends to follow a consistent logic for at least the length of a presidential administration. However, the judiciary is a patchwork of judges appointed by different presidents in different eras, in different regions with different interests. The ultimate arbitrariness of any delineation of the market/society boundary, when coupled with the heterogeneity of the judiciary, makes for a less stable and predictable market/society boundary than the one provided by the specialists at the SEC. 
What if the state stayed out altogether and simply let corporations govern themselves? This would be the equivalent of turning over the corporation to corporate insiders, and would negate the market promoting effects of shareholder rights. Without shareholder oversight, firms would become less focused on profits and efficiency. This realization has led the SEC to long support proxy access when it allows shareholders to limit corporate donations to charities. ${ }^{127}$ Without the oversight of shareholders, management may pursue its own political agenda. For example, Dow Chemical management claimed that during the Vietnam War it sold napalm to the Army out of political and moral commitments, not for business reasons. ${ }^{128}$ Currently, managers may use corporate funds to pursue their policy goals through political spending, which is considered an ordinary business decision and so exempt from shareholder oversight. ${ }^{129}$ These contributions do not need to be disclosed to shareholders. Without shareholder oversight and public scrutiny, it seems unlikely that corporate insiders make political contributions solely in the interest of their companies' profitability. These are reminders that the state's market promotion role is also instrumental in the creation of autonomous markets, because managers are complex actors who are as likely to stray from strict profit-seeking as investors.

Legal definitions of fiduciary duty also serve to reinforce market/society boundaries by keeping many of the largest institutional investors from making non-pecuniary claims on the corporation. ${ }^{130}$ For example, the Employee Retirement Income Security Act of 1974 (ERISA) defines the fiduciary duty of private pension fund managers - including managers of union pension funds -- so that fund mangers must primarily focus on fund performance. ${ }^{131}$ Nonetheless, private institutional investors may engage in process-oriented shareholder activism aimed to establish the rights of shareholders as a class. These rights may then be used by public institutional investors such as NYCERS for values-oriented shareholder activism. 
Given that the SEC has consistently disadvantaged non-pecuniary claims on the corporation, the fact that proxy rights continue to be used as a means to redress social grievances is an indicator that in our "asymmetric society," citizens are not given enough opportunities to influence corporate or state behavior. ${ }^{132}$ Given the frequency with which shareholder activists achieve their policy goals regardless of whether they get their proposal onto a proxy statement, ${ }^{133}$ it is likely that proxy rights will retain a place in social movements' toolkits. However, proxy law reform alone is unlikely to "democratize finance." 134 Rather, the legal system could promote corporate accountability by providing additional access points that are not premised on market autonomy, but which acknowledge that the market is embedded in multiple state and civil fields. Due to the extreme power inequalities in corporate suffrage, broader disclosure requirements would likely do more to democratize corporate governance than enhanced proxy access. ${ }^{135}$ Class action suits and tort law are also powerful means of increasing corporate responsiveness to stakeholders. ${ }^{136}$ Legal definitions of the fiduciary duties of corporate management strike directly at the role of corporations in society. New legal forms such as the "benefit corporation" provide the financial benefits of the corporate form while extending the fiduciary duty of management to include causes and stakeholders specified in the charter. ${ }^{137}$ The benefit corporation, then, is a legal form that fully embraces embeddedness.

Contrary to traditional bureaucratic forms of regulation, these laws attempt to establish corporate accountability through the representation of diverse interests within corporate decisionmaking. The state can promote corporate accountability by creating access points such as these that acknowledge market embeddedness. On the other hand, the state can promote market autonomy by policing these access points and protecting corporate management from nonpecuniary claims. However, the impossibility of a self-enforcing bright line rule separating 
market from society means that neither of these options represents more or less state involvement in the economy: the state must be an active gatekeeper. As financial economists argue, robust stock markets are premised on the state's establishment of a strong set of shareholder rights. As I have argued here, the extent to which these shareholder rights represent general, social rights or narrow, profit-oriented rights has largely been a function of political contestation over state policy. 
Appendix: SEC Denials of No-Action Letters, 1988-1992

\begin{tabular}{|c|c|c|c|c|}
\hline $\begin{array}{l}\text { Targeted } \\
\text { Company/Practice }\end{array}$ & Shareholder Proposal & $\begin{array}{l}\text { Precedent for No- } \\
\text { Action Letter }\end{array}$ & $\begin{array}{l}\text { Reasoning in } \\
\text { Precedents }\end{array}$ & $\begin{array}{l}\text { SEC Reasoning for Reversing } \\
\text { Precedent, Supporting Proposal }\end{array}$ \\
\hline $\begin{array}{l}\text { Pacific Telesis Group } \\
(1988-89)\end{array}$ & $\begin{array}{l}\text { Management should } \\
\text { consult with labor to } \\
\text { study alternatives to } \\
\text { plant closings and the } \\
\text { hiring of contract labor. }\end{array}$ & $\begin{array}{l}\text { Sears, Roebuck \& } \\
\text { Co. No-Action } \\
\text { Letter (1980) }\end{array}$ & $\begin{array}{l}\text { Only management } \\
\text { may decide where to } \\
\text { locate firm property. }\end{array}$ & $\begin{array}{l}\text { Due to "heightened state and federal } \\
\text { interest"138 in community impact of } \\
\text { plant closings and deindustrialization. }\end{array}$ \\
\hline $\begin{array}{l}\text { Tobacco-related } \\
\text { proposals (1990) }\end{array}$ & $\begin{array}{l}\text { Considering health } \\
\text { impact of tobacco re: } \\
\text { company polices on the } \\
\text { manufacturing of } \\
\text { tobacco products. }\end{array}$ & $\begin{array}{l}\text { Dow Chemical } \\
\text { (1969); Kimberly- } \\
\text { Clark Corp. (1987), } \\
\text { Philip Morris Cos. } \\
\text { (1989) }\end{array}$ & $\begin{array}{l}\text { Only management } \\
\text { may decide which } \\
\text { products to produce } \\
\text { and market. }\end{array}$ & $\begin{array}{l}\text { "[P]rior [SEC] letters failed to reflect } \\
\text { adequately the growing significance of } \\
\text { the social and public policy issues } \\
\text { attendant to ... . manufacturing tobacco } \\
\text { products." }\end{array}$ \\
\hline $\begin{array}{l}\text { Transamerica Corp. } \\
(1989-1990)\end{array}$ & $\begin{array}{l}\text { No golden parachutes for } \\
\text { executives (pay } \\
\text { contingent upon a } \\
\text { merger or acquisition). }\end{array}$ & $\begin{array}{l}\text { Georgia-Pacific } \\
\text { Corp. No-Action } \\
\text { Letter (1988) }\end{array}$ & $\begin{array}{l}\text { Golden parachutes are } \\
\text { no different than other } \\
\text { executive pay } \\
\text { decisions, which are } \\
\text { clearly OBDs. }\end{array}$ & $\begin{array}{l}\text { "Golden parachute arrangements raise } \\
\text { substantial policy issues due to anti- } \\
\text { takeover, tax, and legal implications."140 }\end{array}$ \\
\hline $\begin{array}{l}\text { Baltimore Gas and } \\
\text { Electric Company } \\
\text { (1992) and many others }\end{array}$ & $\begin{array}{l}\text { Executive pay to be } \\
\text { capped at twenty-times } \\
\text { the pay of the average } \\
\text { employee. }\end{array}$ & $\begin{array}{l}\text { SEC denial of } \\
\text { Transamerica Corp. } \\
\text { No-Action letter } \\
(1990)\end{array}$ & $\begin{array}{l}\text { Despite the decision } \\
\text { on golden parachutes, } \\
\text { executive pay remains } \\
\text { OBDs. }\end{array}$ & $\begin{array}{l}\text { "There is now widespread public debate } \\
\text { concerning compensation policies and } \\
\text { practices relation to senior executive[s] } \\
\text {. and an increasing recognition that } \\
\text { these matters raise significant policy } \\
\text { issues." } 141\end{array}$ \\
\hline
\end{tabular}

OBD = "Ordinary business decision" 


\section{Acknowledgements}

The author thanks Frank Dobbin, Edward Walker, Carly Knight, Christopher Muller, Kim Pernell-Gallagher, and Nathan Wilmers for helpful feedback. Fred Block provided insightful comments on an earlier version of this project. This paper was presented at the ComparativeHistorical/Political Sociology Mini-Conference at Columbia University in August 2013.

\section{Declaration of Conflicting Interests}

The author is not aware of any conflicting interests.

\section{Funding}

The author was a National Science Foundation Graduate Research Fellow and a Tobin Society Graduate Fellow in Markets and Democracy at the time of writing.

\section{Notes}

1. New York City Employees' Retirement System v. Securities and Exchange Commission, 843 F. Supp. 858, 861 (S.D. NY 1994).

2. Patricia Uhlenbrock, "Roll Out the Barrel: The SEC Reverses Its Stance on EmploymentRelated Shareholder Proposals Under Rule 14a-8 --- Again," Delaware Journal of Corporate Law 25 (2000): 277-308.

3. Kevin Waite, "Ordinary Business Operations Exception to the Shareholder Proposal Rule: A Return to Predictability," Fordham Law Review 64, no. 3 (1995): 1253-1277, 1255.

4. Rafael La Porta, Florencio Lopez-de-Silanes, Andrei Shleifer, and Robert Vishny, "Law and Finance," Journal of Political Economy 106, no. 6 (1998): 1113-1155.

5. Mark Roe, Strong Managers, Weak Owners: The Political Roots of American Corporate Finance (Princeton, NJ: Princeton University Press, 1994); Peter A. Gourevitch and James Shinn, Political Power and Corporate Control: The New Global Politics of Corporate Governance (Princeton, NJ: Princeton University Press, 2005).

6. Karl Polanyi, The Great Transformation (Boston: Beacon Press, 1957 [1944]); Fred Block, "Karl Polanyi and the Writing of The Great Transformation," Theory and Society 32 no. 3 (2003): 275-306; Greta Krippner and Anthony S. Alvarez, "Embeddedness and the Intellectual Projects of Economic Sociology," Annual Review of Sociology 33 (2007): 219-40; Marion Fourcade and Kieran Healy, "Moral Views of Market Society," Annual Review of Sociology 33 (2007): 285-311.

7. Margaret Somers and Fred Block, "From Poverty to Perversity: Ideas, Markets, and Institutions over 200 Years of Welfare Debate," American Sociological Review 70 (2005): 260-287. 
8. Milton Friedman, "The Social Responsibility of Business is to Increase its Profits," New York Times Magazine (13 September 1970).

9. Eugene Fama,. 1970. "Efficient Capital Markets: A Review of Theory and Empirical Work." Journal of Finance 25(2): 383-417.

10. Block, "Great Transformation."

11. Fred Block and Peter Evans, "The State and the Economy," in Neil Smelser and Richard Swedberg, eds., The Handbook of Economic Sociology. (Princeton, NJ: Princeton University Press, 2005), 505-526.

12. Fred Block, Revising State Theory: Essays in Politics and Postindustrialism (Philadelphia: Temple University Press, 1987), 22.

13. Neil Fligstein and Douglas McAdam, A Theory of Fields (Oxford: Oxford University Press, 2012).

14. Michel Callon, "Introduction," in Michel Callon, ed., The Laws of the Markets (Oxford: Blackwell Publishing, 1998), 1-57; Block, "Great Transformation."

15. La Porta et al., "Law and Finance."

16. William Roy, Socializing Capital: The Rise of the Large Industrial Corporation in America, (Princeton, NJ: Princeton University Press, 2007); Bruce Carruthers and Laura Ariovich, "The Sociology of Property Rights," Annual Review of Sociology 30 (2004): 23-46.

17. Block, State Theory; Jeff Manza and Michael McCarthy, "The Neo-Marxist Legacy in American Sociology,” Annual Review of Sociology 37 (2011): 155-183.

18. Neil Fligstein, "Markets as Politics: A Political-Cultural Approach to Market Institutions," American Sociological Review 61 no. 4 (1996):656-73; Fligstein and McAdam, Theory of Fields.

19. Manza and McCarthy, "Neo-Marxist Legacy," 160; Henning Hillmann, "Economic Institutions and the State: Insights from Economic History," Annual Review of Sociology 39 (2013): 251-273, 253.

20. E.g. Lucian Bebchuk, "The Myth of Shareholder Franchise," Virginia Law Review 93 no. 3 (2007): 675-732.

21. E.g. Joseph Stigler, "Public Regulation of the Securities Markets," The Journal of Business 37 no. 2 (1964): 117-142. 
22. La Porta et al., "Law and Finance"; Rafael La Porta, Florencio Lopez-de-Silanes, and Andrei Shleifer, "What Works in Securities Laws?" Journal of Finance 61 no. 1 (2006):1-32; Rafael La Porta, Florencio Lopez-de-Silanes, and Andrei Shleifer, "The Economic Consequences of Legal Origins,” Journal of Economic Literature 46 no. 2 (2008): 285-332.

23. Carruthers and Ariovich, "Property Rights," 23.

24. Lyman Johnson, "Law and the History of Corporate Responsibility," Working Paper No. 6, History of Corporate Responsibility Project (2011).

25. E.g. Bruce Carruthers, City of Capital: Politics and Markets in the English Financial Revolution (Princeton, NJ: Princeton Press, 1996).

26. Douglas McAdam, Political Process and the Development of the Black Insurgency, 19301970, (Chicago: University of Chicago Press, 1982).

27. Edward Walker, Andrew Martin, and John McCarthy, "Confronting the State, the Corporation, and the Academy: The Influence of Institutional Targets on Social Movement Repertoires," American Journal of Sociology 114, no. 1 (2008): 35-76, 41.

28. Hayagreeva Rao and Kumar Sivakumar, "Institutional Sources of Boundary-Spanning Structures: The Establishment of Investor Relations Departments in the Fortune 500 Industrials," Organization Sciences 10, no. 1 (1999): 27-42.

29. David Vogel, Lobbying the Corporation (New York: Basic Books, 1978); David Vogel, The Market for Virtue: The Potential and Limits of Corporate Social Responsibility (Washington, DC: Brookings Institute Press, 2005); W. Trexler Proffitt and Andrew Spicer, "Shaping the Shareholder Activism Agenda: Institutional Investors and Global Social Issues," Strategic Organization 4, no. 2 (2006): 165-190; Brayden King, "A Social Movement Perspective of Stakeholder Collective Action and Influence," Business and Society 47 no. 1 (2008):21-49; Brayden King, "The Tactical Disruptiveness of Movements: Sources of Market and Mediated Disruption in Corporate Boycotts," Social Problems 48 (2011): 491-517; Tim Bartley and Curtis Child, "Movements, Markets and Fields: The Effects of Anti-Sweatshop Campaigns on U.S. Firms, 1993-2000," Social Forces 90 no. 2 (2011): 425-451; Sarah Soule, Contention and Corporate Social Responsibility (New York: Cambridge University Press, 2009).

30. Carruthers, City of Capital; Brayden King and Sarah Soule, "Social Movements as ExtraInstitutional Entrepreneurs: The Effect of Protests on Stock Returns," Administrative Science Quarterly 52 (2007): 413-42; Ion Bogdan Vasi and Brayden King, "Social Movements, Risk Perceptions, and Economic Outcomes," American Sociological Review 77 (2012): 573-596.

31. Nicos Poulantzas, Political Power and Social Classes (London: Verso, 1973); Manza and McCarthy, "The Neo-Marxist Legacy," 158-161.

32. Block, "State Theory." 
33. Peter Evans, Embedded Autonomy: States and Industrial Transformation (Princeton, NJ: Princeton University Press, 1995).

34. Fligstein and McAdam, "Theory of Fields."

35. Proffitt and Spicer, "Shareholder Activism Agenda," 176; Paula Tkac, "One Proxy at a Time: Pursuing Social Change through Shareholder Proposals," Federal Reserve Bank of Atlanta Economic Review 91 no. 3 (2006): 1-20, 17.

36. Bruce Carruthers, Sarah Babb, and Terence Halliday, "Institutionalizing Markets, or the Market for Institutions? Central Banks, Bankruptcy Law and the Globalization of Financial Markets," in John Campbell and Ove Pedersen, eds., The Rise of Neoliberalism and Institutional Analysis (Princeton, NJ: Princeton University Press, 2001), 94-126; Greta Krippner, Capitalizing on Crisis: The Political Origins of the Rise of Finance (Cambridge, MA: Harvard University Press, 2011).

37. Gerald Davis, Managed by the Markets: How Finance Reshaped America (Oxford, UK: Oxford University Press, 2009); Mark Mizruchi, The Fracturing of the American Corporate Elite (Cambridge, MA: Harvard University Press, 2013).

38. Walker, Martin, and McCarthy, "Confronting the State," 54; Brayden King and Nicholas Pearce, "The Contentiousness of Markets: Politics, Social Movements, and Institutional Change in Markets, " Annual Review of Sociology 36 (2010): 249-67.

39. Block, "State Theory," 65-67.

40. Michael Lipsky, "Protest as a Political Resource," American Political Science Review 62 (1968): 1144-58.

41. Max Heirich, The Spiral of Conflict: Berkeley, 1964 (New York: Columbia University Press, 1971).

42. Lewis Coser, The Functions of Social Conflict (New York: The Free Press, 1956), 46-47.

43. E.E. Schattschneider, The Semisovereign People (Fort Worth, TX: Hartcourt Brace Jovanovich, 1960).

44. Fligstein and McAdam, "Theory of Fields," 105.

45. Ralph Nader, Mark Green and Joel Seligman, Taming the Giant Corporation (New York: W.W. Norton \& Company, 1976); Proffitt and Spicer, "Shareholder Activism Agenda."

46. Michael Useem, Executive Defense: Shareholder Power and Corporate Reorganization (Cambridge, MA: Harvard University Press, 1993); Gerald Davis and Tracey Thompson, "A Social Movement Perspective on Corporate Control," Administrative Science Quarterly 39 (1994):141-73; Rao and Sivakumar, "Boundary-Spanning Structures." 
47. Nader, Green, and Seligman, "Taming the Giant Corporation"; Lewis Gilbert, "The Proxy Proposal Rule of the Securities and Exchange Commission." University of Detroit Law Journal 33 (1955): 191-212; John Fedders, "Qualitative Materiality: The Birth, Struggles, and Demise of an Unworkable Standard." Catholic University Law Review 48 (1998): 41-91.

48. Ray Garrett, "What the SEC Expects of Corporate Directors," Arthur D. Little Corporate Directors Conference (Washington, D.C., 17 December 1974); Ray Garrett, "The Disclosure Philosophy," Union League Club (New York, 20 February 1975), 4. Note that these addresses, as well as all sources marked SEC Historical Society, are available online at www.sechistorical.org.

49. Bruce Alan Mann, “Letter to Quinton F. Seamons on SEC Commissioner John R. Evan's Comments on Disclosure," SEC Historical Society (1975); Walter E. Hanson, "Letter and Memo to SEC Chairman Roderick M. Hills on Improper Payments," SEC Historical Society (1976).

50. A more detailed account of the SEC's post-Watergate activities can be found in a working paper: Carl Gershenson, "The SEC's Failed Corporate Governance Revolution."

51. Robin Stryker, "Beyond History Versus Theory: Strategic Narrative and Sociological Explanation.” Sociological Methods \& Research 24, no. 3 (1996): 304-352.

52. Alexander George and Andrew Bennett, Case Studies and Theory Development in the Social Sciences (Cambridge, MA: MIT Press, 2005).

53. SEC, "Everything You Always Wanted to Know About SEC Commissioners (But Were Afraid to Ask)," SEC Historical Society (1974).

54. Christopher Foreman, Jr., Signals from the Hill: Congressional Oversight and the Challenge of Social Regulation (New Haven, CT: Yale University Press, 1988).

55. Anne Khademian, The SEC and Capital Market Regulation: The Politics of Expertise (Pittsburgh: University of Pittsburg, 1992), 67, 112-113; Roberta Karmel, Regulation by Prosecution: The Securities and Exchange Commission vs. Corporate America (New York: Simon and Schuster, 1982).

56. SEC, "Everything You Always Wanted to Know"; Khademian, Politics of Expertise, 93-94, 105.

57. The SEC's generally strong reputation has taken a hit in the $21^{\text {st }}$ Century due to Enron and the financial crisis, among other issues. However, not all scholars see the "revolving door" as the cause of this deteriorating reputation, e.g. Khademian, Politics of Expertise, 89-90; Ed DeHaan, Simi Kedia, Kevin Joh, and Shivaram Rajgopal, "Does the Revolving Door Affect the SEC's Enforcement Outcomes?" Rock Center for Corporate Governance, Working Paper No. 187 (2014). 
58. Jill Fisch, "The Transamerica Case," in Jonathan R. Macey, ed., The Iconic Cases in Corporate Law (St. Paul, MN: Thomson West, 2008), 46-78, 46.

59. “Amendment of Regulation X-14,” 5 Fed. Reg. Title 174, 174-177 (Jan. 12, 1940).

60. "Solicitation of Proxies Under the Act," 7 Fed. Reg. 10655, 10656 (Dec. 22, 1942).

61. Medical Committee for Human Rights v. Securities and Exchange Commission, 432 F.2d 659, 678 (D.C. Cir. 1970).

62. Robert O'Brien, “Address before the Conference Board," SEC Historical Society (New York, Jan. 21, 1943).

63. Medical Committee, 432 F.2d 659 at 677.

64. Joseph Roy, "Non-Traditional Activism: Using Shareholder Proposals to Urge LGBT NonDiscrimination Protection," Brooklyn Law Review 74 (2009): 1513-1538, 1519; For logics of appropriateness, Roger Friedland and Robert Alford, "Bringing Society Back In: Symbols, Practices, and Institutional Contradictions," in Walter W. Powell and Paul J. DiMaggio, eds., The New Institutionalism in Organizational Analysis (Chicago: University of Chicago Press, 1991).

65. Louis Loss, Securities Regulation (New York: Little, Brown and Company, 1961), 906.

66. Peck v. Greyhound Corp., 97 F. Supp. 679 (S.D. NY 1951).

67. Medical Committee, 432 F.2d 659 at 678.

68. Donald Schwartz, "The Public-Interest Proxy Contest: Reflections on Campaign GM," Michigan Law Review 69 (1971): 419-538, 444.

69. Fisch, “Transamerica Case," 50-53.

70. Ibid., 46.

71. La Porta et al., "Law and Finance."

72. Gilbert, "Proxy Proposal Rule.”

73. Schwartz, "Reflections on Campaign GM," 443.

74. Medical Committee, 432 F.2d 659 at 679.

75. Gilbert, "Proxy Proposal Rule," 211; Waite, "Return to Predictability," 1258; Tkac, "One Proxy at a Time," 14. 
76. Medical Committee, 432 F.2d 659.

77. Schwartz, "Reflections on Campaign GM," 434.

78. Neal Caren, Raj Andrew Ghoshal, and Vanesa Ribas, "A Social Movement Generation: Cohort and Period Trends in Protest Attendance and Petition Signing," American Sociological Review 76 no. 1 (2011): 125-151.

79. Talner, Lauren. 1983. The Origins of Shareholder Activism. Washington, D.C.: Investor Responsibility Research Center.

80. Nader, Green, and Seligman, "Taming the Giant Corporation"; Vogel, Lobbying the Corporation.

81. Schwartz, "Reflections on Campaign GM," 425.

82. Marc Galanter, "Why the 'Haves' Come Out Ahead: Speculations on the Limits of Legal Change," Law and Society Review 9 (1974): 95-160.

83. Frank Dobbin and Jiwook Jung, "The Misapplication of Mr. Michael Jensen: How Agency Theory Brought Down the Economy and Why It Might Again," in Michael Lounsbury and Paul M. Hirsch, eds., Markets on Trial: The Economic Sociology of the U.S. Financial Crisis, (Bingley, UK: Emerald Group Publishing, 2010), 29-64.

84. Proffitt and Spicer, "Shareholder Activism Agenda."

85. Harry Blackmun, "Note to Justice Thurgood Marshall," SEC Historical Society (22 December 1971).

86. Medical Committee 432 F.2d 659 at 409-410; James Galbraith, The New Industrial State (Boston: Houghton Mifflin Company, 1967).

87. Ray Garrett, "Corporate Directors and the Federal Securities Laws," 13th Annual Corporate Counsel Institute (Chicago, 3 October 1974), 8.

88. In re: Franchard Corp., 42 SEC 163 (SEC 1964).

89. David Doherty, “The SEC's Management Fraud Program.” Business Lawyer 31 (1976): $1279-1282,1279$.

90. Fedders, "Qualitative Materiality."

91. Ray Garrett, "The Role of Professionals," Address to San Diego County Bar Association. (San Diego, 15 March 1974), 4; Ray Garrett Jr., "Professional Responsibility and the Securities Laws," State Bar of Texas (San Antonio, 4 July 1974), 5. 
92. Garrett, "Role of Professionals," 11; also Garrett, "Corporate Directors and Securities Laws," 13; Garrett, "Professional Responsibility," 2,7; Ray Garrett, "Problems of Professional Responsibility,” American Bar Association (Montreal, 30 May 1974), 8.

93. Ray Garrett, "Changing Concepts of Business Ethics and the Responsibilities of Business Advisors," ABA National Institute (New York, 3 October 1974), 13; also Garret, "Corporate Directors and Securities Laws," 4; Garrett, "What the SEC Expects," 19; Garrett, "Disclosure Philosophy," 11, 16; Ray Garrett, "Disclosure Rules and New Concerns," American Society of Corporate Secretaries, (Atlanta, 16 January 1975), 15.

94. Garrett, "Disclosure Philosophy," 15; also Ray Garrett, "Disclosures and Corporate Management," Wharton Graduate Business School Club of New York (New York, 14 April 1975), 5.

95. A.A. Sommer, "Thoughts for the Insurance Company Director," American Bar Association Annual Meeting. (Honolulu, 14 August 1974), 4; also A.A. Sommer, "Professional Responsibility: How Did We Get Here?" ABA National Institute (New York, 4 October 4 1974), 12.

96. Garrett, "Professional Responsibility," 2; also Garrett, "Corporate Directors and Securities Laws," 13.

97. John R. Evans, "Of Boycotts and Bribery and Corporate Accountability," SEC Historical Society (Washington, D.C, 5 October 1976).

98. "SEC Voluntary Compliance Program on Corporate Disclosure," House of Representatives Report No. H502-27 (1976); "Federal Regulation and Regulatory Reform," House of Representatives Report No. H502-40 (1976).

99. Ray Garrett, "Homily on the Glories of Right Conduct and the Wages of Sin," American Society of Corporate Secretaries (White Sulphur Springs, WV, 27 June 1975), 18-19.

100. Ibid., 18.

101. Ibid., 19.

102. Ibid., 20.

103. Ibid., 9.

104. Ibid., 18.

105. A.A. Sommer, "Crisis and Corporate Community." Midwest Securities Commissioners Association Conference (Aspen, CO, 21 July 1975), 20; also A.A. Sommer, "The Limits of Disclosure." Wharton-AICPA Advanced Management Program for CPA Firm Partners 
(Philadelphia, 24 June 1975); A.A. Sommer, “The Slippery Slope of Materiality.” Practising Law Institute (New York, 8 December 1975).

106. Karmel, Regulation by Prosecution; Fedders, "Qualitative Materiality"; Gershenson, "Failed Revolution."

107. "Adoption of Amendments Relating to Proposals by Security Holders," 41 Fed. Reg. 52994 (Dec. 3, 1976).

108. Fisch, “The Transamerica Case," 57.

109. Amalgamated Clothing and Textile Workers Union v. Wal-Mart Stores, 821 F. Supp. 877, 890 (S.D. NY 1993).

110. David Vice and Steve Coll, Eagle on the Street (New York: Charles Scribner's Sons, 1991).

111. "Relating to Proposals by Security Holders," 48 Fed. Reg. 36218, 38219 (Aug. 23, 1983).

112. Herbert Gocha, “The 1980's Amendments to Shareholder Proposal Rule 14a-8: A Final Damper on Dissent?” University of Toledo Law Review 17 (1986): 411-440, 426.

113. Lovenheim v. Iroquois Brands, Ltd., 618 F. Supp. 554, 556 (D.C. 1985).

114. Proffitt and Spicer, "Shareholder Activism Agenda," 171.

115. Ibid., 181.

116. Waite, "Return to Predictability," 1267.

117. Roosevelt v. Du Pont de Nemours and Co., 958 F.2d 416 (D.C. Cir. 1992), 424; Amalgamated Clothing 821 F. Supp. 877 at 885.

118. Uhlenbrock, “SEC Reverses Its Stance,” 294-295.

119 Ibid., 294.

120. Ibid., 296.

121. Roy, "Non-Traditional Activism," (1520).

122. A glimpse at the titles of articles on proxy access makes this point: Shireen Rahnema, "The SEC's Reversal of Cracker Barrel: A Return to Uncertainty," University of Miami Business Law Review (1998), 273-307; Uhlenbrock, "SEC Reverses Stance on Employment-Related Shareholder Proposals --- Again," 79-80; Jill Fisch, "The Destructive Ambiguity of Federal Proxy Access," Emory Law Journal 61 (2012): 435-500; Jean Martin Amerson, "In Praise of 
Process: Examining the SEC, Rule 14a-8(i)(8), and AFSCME v. AIG, "Journal of Business \& Technology Law 5, no. 1(2010): 23-43, 26; Waite, "Return to Predictability," 1258; Fisch, "The Transamerica Case," 60-63.

123. Roy, "Non-Traditional Activism."

124. Amerson, "In Praise of Process"; Fisch, "Destructive Ambiguity."

125. Jill Fisch, "The Long Road Back: Business Roundtable and the Future of SEC Rulemaking," Seattle University Law Review 36 (2013): 695-730.

126. Davis, Managed by the Markets, 51-52.

127. Roy, "Non-Traditional Activism," 1535; Thomas Monaghan, "Annual Stockholders' Meetings: Some Legal and Practical Problems," Baylor Law Review 16 (1964): 129-144, 134.

128. Medical Committee, 432 F.2d 659 at 681.

129. Lucian Bebchuk and Robert Jackson, Jr., "Corporate Political Speech: Who Decides?" Harvard Law Review 124 (2010): 83-117.

130. Joakim Sandberg, "Socially Responsible Investment and Fiduciary Duty: Putting the Freshfields Report into Perspective,” Journal of Business Ethics 101 (2011), 143-162.

131. Robert Lynn, "Investing Pension Funds for Social Goals Requires Changing the Law," University of Colorado Law Review 53 (1981), 101-116. Congress passed ERISA two years before the SEC adopted it two-pronged rule in 1976, meaning the SEC knew that some of the most powerful institutional investors could not use this new rule.

132. James Coleman, Asymmetric Society (Syracuse, NY: Syracuse University Press, Coleman, 1982).

133. Roy, "Non-Traditional Activism," 1515.

134. Fred Block, “Democratizing Finance,” Politics \& Society 42 (2014): 3-28.

135. Archon Fung, "Infotopia: Unleashing the Democratic Potential of Transparency," Politics \& Society 41, no. 2 (2013): 183-212.

136. Gocha, "Final Damper on Dissent?", 437; John Skrentny, "Law and the American State," Annual Review of Sociology 33 (2006): 213-244.

137. J. William Callison, "Benefit Corporations, Innovation and Statutory Design," Regent University Law Review 26 no. 1 (2013): 143-165.

138. Waite, "Return to Predictability," 1267. 
139. Ibid., 1268.

140. Ibid., 1269.

141. Ibid., 1270.

\section{Author Biography}

Carl Gershenson (cgershen@fas.harvard.edu) is a graduate student in Harvard University's Department of Sociology. The main focus of his research is economic sociology and political sociology with a special focus on corporations, markets, and the state. His dissertation examines the development of the corporate form and elite social networks in antebellum America. 